\title{
Enhanced $\beta$-carotene and Biomass Production by Induced Mixotrophy in Dunaliella salina across a Combined Strategy of Glycerol, Salinity, and Light
}

\author{
Willian Capa-Robles ${ }^{1}$, Ernesto García-Mendoza ${ }^{2} \mathbb{D}$ and José de Jesús Paniagua-Michel ${ }^{1, *}$ \\ 1 Department of Marine Biotechnology, Centro de Investigación Científica y de Educación Superior de \\ Ensenada (CICESE), 22860 Ensenada, Baja California, Mexico; wcapa@cicese.edu.mx \\ 2 Department of Biological Oceanography, Centro de Investigación Científica y de Educación Superior de \\ Ensenada (CICESE), 22860 Ensenada, Baja California, Mexico; ergarcia@cicese.mx \\ * Correspondence: jpaniagu@cicese.mx; Tel.: +52-646-1745050
}

\section{check for} updates

Citation: Capa-Robles, W.; García-Mendoza, E.;

Paniagua-Michel, J.d.J. Enhanced

$\beta$-carotene and Biomass Production

by Induced Mixotrophy in Dunaliella salina across a Combined Strategy of Glycerol, Salinity, and Light.

Metabolites 2021, 11, 866.

https://doi.org/10.3390/

metabo11120866

Academic Editor: David J. Beale

Received: 30 September 2021

Accepted: 9 December 2021

Published: 13 December 2021

Publisher's Note: MDPI stays neutral with regard to jurisdictional claims in published maps and institutional affiliations.

Copyright: (c) 2021 by the authors. Licensee MDPI, Basel, Switzerland. This article is an open access article distributed under the terms and conditions of the Creative Commons Attribution (CC BY) license (https:// creativecommons.org/licenses/by/ $4.0 /)$.

\begin{abstract}
Current mixotrophic culture systems for Dunaliella salina have technical limitations to achieve high growth and productivity. The purpose of this study was to optimize the mixotrophic conditions imposed by glycerol, light, and salinity that lead to the highest biomass and $\beta$-carotene yields in D. salina. The combination of $12.5 \mathrm{mM}$ glycerol, $3.0 \mathrm{M}$ salinity, and $50 \mu \mathrm{mol}$ photons $\mathrm{m}^{-2} \mathrm{~s}^{-1}$ light intensity enabled significant assimilation of glycerol by $D$. salina and consequently enhanced growth $\left(2.1 \times 10^{6}\right.$ cell $\left.\mathrm{mL}^{-1}\right)$ and $\beta$-carotene accumulation $\left(4.43 \mathrm{pg}^{-1}{ }^{-1}\right)$. The saline and light shock induced the assimilation of glycerol by this microalga. At last stage of growth, the increase in light intensity $\left(300 \mu \mathrm{mol}\right.$ photons $\left.\mathrm{m}^{-2} \mathrm{~s}^{-1}\right)$ caused the $\beta$-carotene to reach values higher than $30 \mathrm{pg}$ cell $^{-1}$ and tripled the $\beta$-carotene values obtained from photoautotrophic cultures using the same light intensity. Increasing the salt concentration from 1.5 to $3.0 \mathrm{M} \mathrm{NaCl}$ (non-isosmotic salinity) produced higher growth and microalgal $\beta$-carotene than the isosmotic salinity $3.0 \mathrm{M} \mathrm{NaCl}$. The mixotrophic strategy developed in this work is evidenced in the metabolic capability of $D$. salina to use both photosynthesis and organic carbon, viz., glycerol that leads to higher biomass and $\beta$-carotene productivity than that of an either phototrophic or heterotrophic process alone. The findings provide insights into the key role of exogenous glycerol with a strategic combination of salinity and light, which evidenced unknown roles of this polyol other than that in osmoregulation, mainly on the growth, pigment accumulation, and carotenogenesis of D. salina.
\end{abstract}

Keywords: Dunaliella; glycerol; $\beta$-carotene; photosynthesis; mixotrophy

\section{Introduction}

Microalgae are one of the primary aquatic resources with the potential for exploitation and cultivation to obtain economically valuable compounds. The chlorophyte Dunaliella salina is the supreme and natural source of $\beta$-carotene, a carotenoid with bioactive roles such as provitamin $A$, colorant, antioxidant, antimicrobial, pro-apoptotic, anti-aging immunomodulator, and anticarcinogenic $[1,2]$. The biomass and $\beta$-carotene of this microalga are used extensively in the food, feed, pharmaceutical, biomedical, and nutraceutical and cosmeceutical industries [3,4]. Moreover, this halophilic microorganism is a promising source of other carotenoids (zeaxanthin, lutein, and $\alpha$-carotene), vitamins, lipids, and proteins $[3,5,6]$. For a long time, the uniqueness of $D$. salina to thrive under extreme environmental conditions has been worldwide exploited at photoautotrophic production systems. However, yield and productivity under this practice are low due to photoinhibition, photo-oxidative damage, and self-shading of cultures intended to produce high cell densities [7]. Mixotrophic systems are attractive due to their low light requirements and large availability of carbon (inorganic and organic), contributing to improved growth rate, biomass, and extensive synthesis of metabolites. Mixotrophy involves the concomitant, 
simultaneous, and efficient metabolism between photosynthesis and respiration. Consequently, various metabolic pathways and sub-routes to incorporate and allocate carbon and energy are activated in microalgae $[8,9]$. Today, organic carbon nutrition and mixotrophy linked to metabolic pathways represent new scenarios in expanding knowledge and diversification of the metabolism and physiology of microalgae of environmental and economic importance.

Efforts to develop mixotrophic growth media for $D$. salina and many other microalgae are currently underway. The growth of $D$. salina on glucose $[10-12]$ and acetate $[10,13,14]$ supplemented media was reported, but they still exhibit predominantly low growth rates or a very low amount of $\beta$-carotene. Regarding substrates, glucose has the disadvantage of reducing photochemical $\mathrm{O}_{2}$ evolution, cellular affinity for $\mathrm{CO}_{2}$, and the synthesis of the Calvin cycle enzymes in microalgae [15]. This sugar is relatively expensive compared to other organic substrates [16]. Acetate can be toxic in high concentrations for various microorganisms [17] and sometimes is an inadequate substrate for $\beta$-carotene synthesis in microalgae [13]. In recent years, the use of glycerol for the mixotrophic production of biomass and carotenoids from microalgae, including D. salina, has been an important initiative by some groups of research [18-21]. Glycerol can be assimilated properly under respiratory conditions by photosynthetic microorganisms [22]. Moreover, this polyol lacks toxic effects on microalgal cells even at high concentrations [23]. This $\mathrm{C}_{3}$ molecule is the major by-product of the biodiesel industry (known as crude glycerol). This hypersaline waste could promote the growth and production of halophilic carotenogenic microorganisms [24]. Meanwhile, D. salina synthesizes glycerol to succeed in media and environments containing $\mathrm{NaCl}$ concentrations from about $0.05 \mathrm{M}$ to saturation (around 5.5 M) [25,26]. Unlike other organic carbon substrates, the role of glycerol on the physiology and metabolism of $D$. salina may involve increased cell growth, $\beta$-carotene synthesis, and carotenogenesis.

Currently, entrepreneurs and companies have difficulties in implementing mixotrophic microalgal production under optimal culture conditions to maximize the yield and productivity in this biosystem [27]. Therefore, the substrate concentration and the environmental factors that best stimulate the mixotrophic metabolism of $D$. salina on glycerol must be optimized. Likewise, the role of glycerol on generating more biomass, $\beta$-carotene synthesis and carotenogenesis from D. salina must be explained. To investigate these gaps in knowledge of the induced mixotrophic metabolism, we assessed how glycerol, salinity, and light intensity under optimized conditions can stimulate the simultaneous and competitive production of biomass and $\beta$-carotene in this microalga under mixotrophic culture conditions. This paper presents the individual and combined effect of glycerol level, salinity, and light intensity on the nutritional and metabolic capacities of $D$. salina to maximize the cellular growth and carotenoids content under mixotrophy. Moreover, this research reveals for the first time the relationship between growth and carotenogenesis, especially of $\beta$-carotene in D. salina cultured mixotrophically on glycerol.

\section{Results}

\subsection{Effect of Glycerol Concentration on Mixotrophic Culture of D. salina under $1.5 \mathrm{M} \mathrm{NaCl}$ Isosmotic Salinity}

Due to the heterogeneity of both the salinities and glycerol levels, and the cell growth reported from previous studies $[14,20,28]$, the effect of glycerol concentration on the culture of D. salina under better growth isosmotic conditions (1.5 M NaCl) [29] was evaluated. This saline condition and $12.5 \mathrm{mM}$ glycerol promoted the best growth of this microalga $\left(1.19 \times 10^{6}\right.$ cells $\left.\mathrm{mL}^{-1}\right)(p<0.05)$, even exceeding cell density obtained in photoautotrophic cultures (IM) (Figure 1). In addition, the higher concentrations of glycerol yielded the lowest cell growth. Table 1 shows the lower contents for $\mathrm{Chl} a$, similar for $\mathrm{Chl} b$, and higher for $\beta$ Car in this alga under $12.5 \mathrm{mM}$ glycerol compared to IM. 


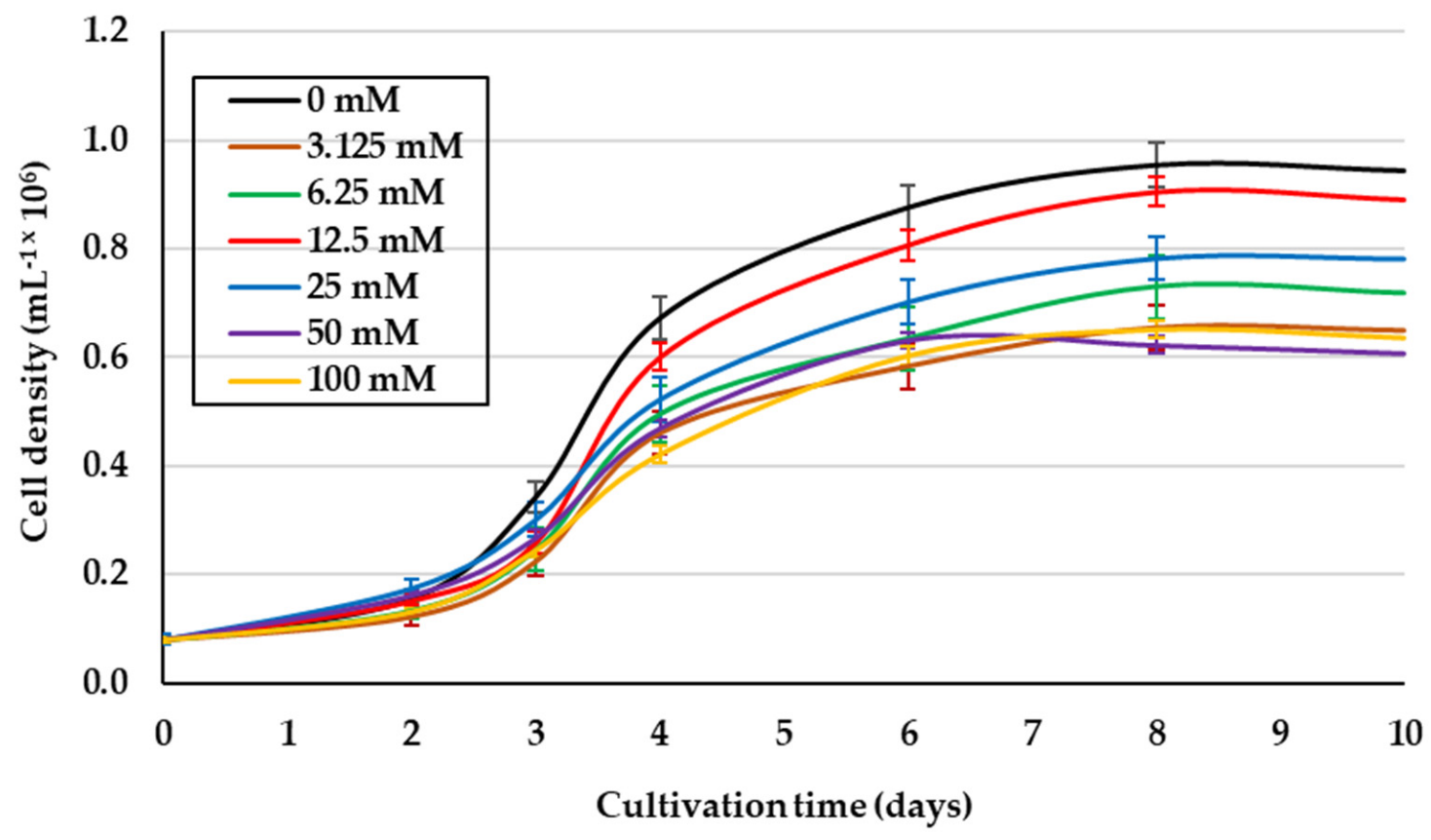

Figure 1. Cell density of D. salina cultured with different concentrations of glycerol (Gly). Salinity and light intensity were $1.5 \mathrm{M} \mathrm{NaCl}$ and $50 \mu \mathrm{mol}$ photons $\mathrm{m}^{-2} \mathrm{~s}^{-1}$, respectively. Values correspond to the mean \pm standard deviation of three replicates.

Table 1. Chl $a, \mathrm{Chl} b$, BCar, and culture $\mathrm{pH}$ of D. salina grown under $12.5 \mathrm{mM}$ Gly and photoautotrophic control. Efficient salinity for growth and light intensity were $1.5 \mathrm{M} \mathrm{NaCl}$ and $50 \mu \mathrm{mol}$ photons $\mathrm{m}^{-2} \mathrm{~s}^{-1}$, respectively. Values in the same column with different superscript are significantly different.

\begin{tabular}{ccccc}
\hline Culture Medium & $\begin{array}{c}\text { Chl } \boldsymbol{a} \\
\text { (pg cell }^{-1} \text { ) }\end{array}$ & $\begin{array}{c}\text { Chl } \boldsymbol{b} \\
\left.\text { (pg cell }^{-1}\right)\end{array}$ & $\begin{array}{c}\text { BCar } \\
\left.\text { (pg cell }^{-1}\right)\end{array}$ & Final pH \\
\hline IM & $2.48 \pm 0.18^{\mathrm{a}}$ & $0.65 \pm 0.05^{\mathrm{a}}$ & $1.24 \pm 0.09^{\mathrm{b}}$ & $8.32 \pm 0.11^{\mathrm{a}}$ \\
$\mathrm{IM}+12.5 \mathrm{mM}$ Gly & $1.22 \pm 0.09^{\mathrm{b}}$ & $0.62 \pm 0.05^{\mathrm{a}}$ & $1.90 \pm 0.14^{\mathrm{a}}$ & $7.24 \pm 0.05^{\mathrm{b}}$ \\
$p$-value & $p<0.00012$ & $p>0.495$ & $p<0.002$ & $p<0.00008$ \\
\hline
\end{tabular}

\subsection{Combined Effect of Glycerol, Light, and Salinity on Mixotrophic Culture of D. salina}

Figure $2 \mathrm{a}-\mathrm{d}$ shows the effect of lower glycerol level combined with different light intensities and salinities on the growth and pigments of D. salina. The highest cellular yields were obtained with $12.5 \mathrm{mM}$ glycerol, 3.0 M non-isosmotic salinity, and $50 \mu \mathrm{mol}$ photons $\mathrm{m}^{-2} \mathrm{~s}^{-1}$ light intensity (Figure $\left.2 \mathrm{c}\right)(p<0.05)$, which exceeded threefold and twofold the microalgal productivity of the controls (IM) under 3.0 and $1.5 \mathrm{M} \mathrm{NaCl}$, respectively (Figure 2a,c). The remarkable increase in chlorophylls $a$ and $b$, and $\beta$ Car (Table 2) was observed when D. salina was grown under the optimal glycerol treatment (12.5 mM glycerol, 3.0 M non-isosmotic salinity and $50 \mu \mathrm{mol}$ photons $\mathrm{m}^{-2} \mathrm{~s}^{-1}$ light intensity). The analysis of culture $\mathrm{pH}$ in $D$. salina under the optimum glycerol treatment tended to mild basicity (7.0-8.2) (Table 2).

To stimulate the massive synthesis of $\beta$-carotene, $D$. salina cells that had reached their maximum at the seventh day of culture on inorganic medium enriched with glycerol were exposed to higher light intensity (from 50 to $300 \mu \mathrm{mol}$ photons $\mathrm{m}^{-2} \mathrm{~s}^{-1}$ ) [30] for a period of three days. Figures 3 and 4 show changes in the pigment content of D. salina under mixotrophic cultures at changed light intensity. In glycerol treatments under high light, chlorophyll $a$ and $b$ levels remained almost constant, whereas their levels of $\beta$-carotene and zeaxanthin increased compared to those treatments under low light. 
$0 \mathrm{mM}$

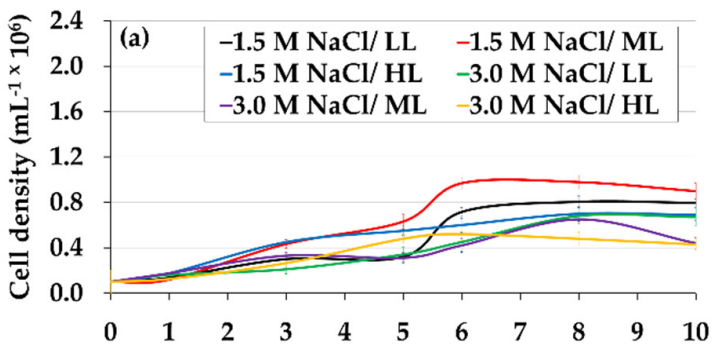

$12.5 \mathrm{mM}$

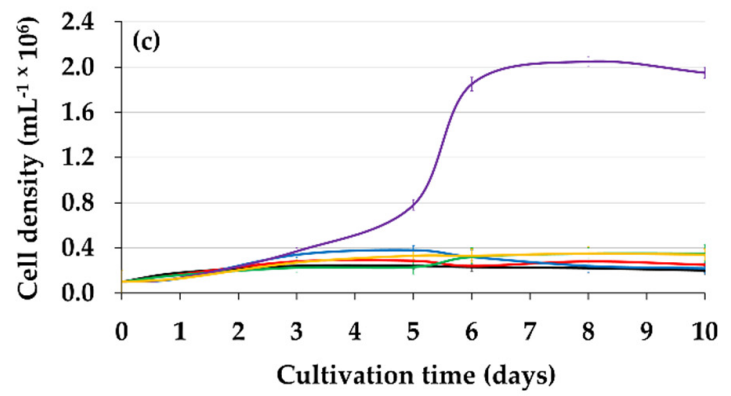

$6.25 \mathrm{mM}$

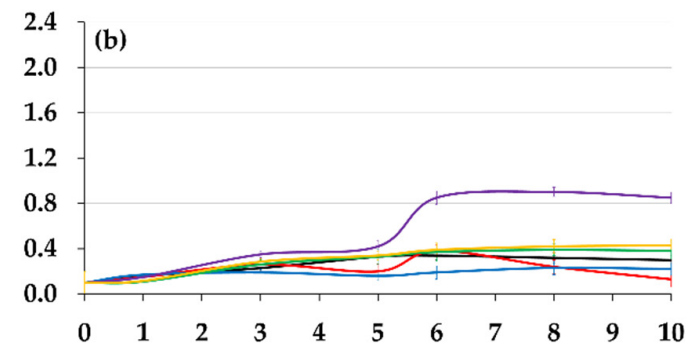

$25 \mathrm{mM}$

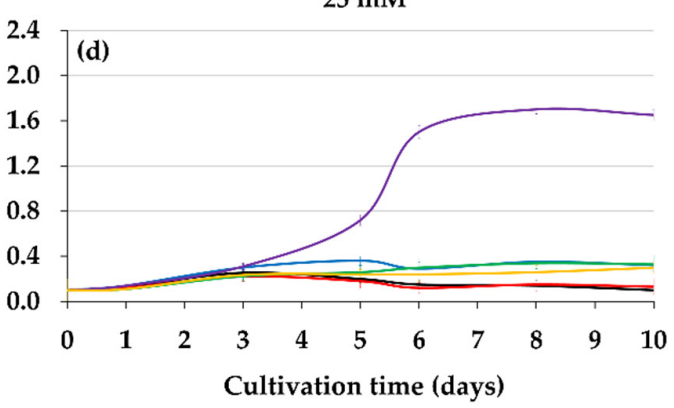

Figure 2. Cell density of $D$. salina cultured with different combinations of glycerol, salinity, and light intensity. The following interaction is indicated: glycerol, $0 \mathrm{mM}(\mathbf{a}), 6.25 \mathrm{mM}(\mathbf{b}), 12.5 \mathrm{mM}$ (c) and $25 \mathrm{mM}$ (d) with 1.5 and $3.0 \mathrm{M} \mathrm{NaCl}$ as well as with 10,50 and $100 \mu \mathrm{mol}$ photons $\mathrm{m}^{-2} \mathrm{~s}^{-1}$ respectively. Values correspond to the mean \pm standard deviation of three replicates.

Table 2. Chl $a$, Chl $b$, BCar, and culture $\mathrm{pH}$ of D. salina grown under different levels of glycerol, non-isosmotic salinity, and light intensity. The initial $\mathrm{pH}$ range was 6.20-6.35, and the final $\mathrm{pH}$ corresponds to the 7th day of cultivation. Values in the same columns with different superscript are significantly different.

\begin{tabular}{|c|c|c|c|c|c|c|}
\hline $\begin{array}{c}\text { Glycerol } \\
\text { Level (mM) }\end{array}$ & $\begin{array}{c}\text { Salinity (M } \\
\text { NaCl) }\end{array}$ & $\begin{array}{c}\text { Light Intensity } \\
\text { ( } \mu \mathrm{mol} \text { Photons } \\
\mathrm{m}^{-2} \mathrm{~s}^{-1} \text { ) }\end{array}$ & $\begin{array}{c}\mathrm{Chl} a \\
\left(\operatorname{pg~cell}^{-1}\right)\end{array}$ & $\begin{array}{c}\text { Chl } b \\
\left(\text { pg cell }^{-1}\right)\end{array}$ & $\begin{array}{c}\text { Bcar } \\
\left(\text { pg cell }^{-1}\right)\end{array}$ & Final $\mathrm{pH}$ \\
\hline 0 & 1.5 & 10 & $3.95 \pm 0.19^{b}$ & $1.21 \pm 0.06^{\mathrm{c}}$ & $1.56 \pm 0.08^{\mathrm{e}}$ & $8.55 \pm 0.42^{a b}$ \\
\hline 6.25 & 1.5 & 10 & $2.47 \pm 0.12^{c}$ & $1.33 \pm 0.07^{c}$ & $2.28 \pm 0.11^{\mathrm{d}}$ & $7.65 \pm 0.33^{b}$ \\
\hline 12.5 & 1.5 & 10 & $2.24 \pm 0.11^{d}$ & $1.71 \pm 0.08^{b}$ & $2.61 \pm 0.13^{c}$ & $7.50 \pm 0.37^{b}$ \\
\hline 25.0 & 1.5 & 10 & $2.75 \pm 0.13^{c}$ & $2.36 \pm 0.11^{\mathrm{a}}$ & $2.19 \pm 0.11^{\mathrm{d}}$ & $7.42 \pm 0.38^{b}$ \\
\hline 0 & 1.5 & 50 & $2.18 \pm 0.11^{\mathrm{d}}$ & $0.59 \pm 0.02^{\mathrm{d}}$ & $1.37 \pm 0.07^{\mathrm{e}}$ & $9.05 \pm 0.45^{\mathrm{a}}$ \\
\hline 6.25 & 1.5 & 50 & $2.90 \pm 0.14^{\mathrm{c}}$ & $1.30 \pm 0.06^{\mathrm{c}}$ & $1.67 \pm 0.08^{b}$ & $7.68 \pm 0.38^{b}$ \\
\hline 12.5 & 1.5 & 50 & $3.53 \pm 017^{b}$ & $1.33 \pm 0.06^{c}$ & $2.20 \pm 0.11^{\mathrm{d}}$ & $7.58 \pm 0.37^{b}$ \\
\hline 25.0 & 1.5 & 50 & $3.27 \pm 0.16^{b}$ & $1.57 \pm 0.07^{b}$ & $1.63 \pm 0.08^{\mathrm{e}}$ & $7.50 \pm 0.35^{b}$ \\
\hline 0 & 1.5 & 100 & $4.03 \pm 0.20^{\mathrm{ab}}$ & $1.05 \pm 0.05^{\mathrm{cd}}$ & $2.76 \pm 0.14^{\mathrm{c}}$ & $9.25 \pm 0.46^{\mathrm{a}}$ \\
\hline 6.25 & 1.5 & 100 & $1.56 \pm 0.08^{\mathrm{e}}$ & $0.79 \pm 0.04^{\mathrm{d}}$ & $2.28 \pm 0.11^{\mathrm{d}}$ & $7.71 \pm 0.38^{b}$ \\
\hline 12.5 & 1.5 & 100 & $3.63 \pm 0.18^{b}$ & $1.54 \pm 0.07^{b}$ & $2.82 \pm 0.14^{\mathrm{c}}$ & $7.82 \pm 0.39^{b}$ \\
\hline 25.0 & 1.5 & 100 & $2.51 \pm 0.12^{c}$ & $1.00 \pm 0.05^{\mathrm{cd}}$ & $2.66 \pm 0.13^{c}$ & $7.63 \pm 0.38^{b}$ \\
\hline 0 & 3.0 & 10 & $2.47 \pm 0.13^{c}$ & $1.64 \pm 0.08^{b}$ & $2.16 \pm 0.11^{\mathrm{d}}$ & $8.38 \pm 0.42^{a b}$ \\
\hline 6.25 & 3.0 & 10 & $2.28 \pm 0.11^{\mathrm{d}}$ & $2.02 \pm 0.10^{a}$ & $2.77 \pm 0.14^{\mathrm{c}}$ & $7.84 \pm 0.39^{b}$ \\
\hline 12.5 & 3.0 & 10 & $2.90 \pm 0.15^{\mathrm{c}}$ & $1.58 \pm 0.08^{b}$ & $2.11 \pm 0.10^{\mathrm{d}}$ & $7.67 \pm 0.38^{b}$ \\
\hline 25.0 & 3.0 & 10 & $2.87 \pm 0.14^{c}$ & $1.51 \pm 0.08^{b}$ & $2.12 \pm 0.11^{\mathrm{d}}$ & $7.60 \pm 0.38^{b}$ \\
\hline 0 & 3.0 & 50 & $1.82 \pm 0.09^{\mathrm{e}}$ & $0.45 \pm 0.02^{\mathrm{d}}$ & $1.28 \pm 0.06^{\mathrm{f}}$ & $8.42 \pm 0.42^{\mathrm{ab}}$ \\
\hline 6.25 & 3.0 & 50 & $2.48 \pm 0.12^{\mathrm{d}}$ & $0.75 \pm 0.04^{\mathrm{d}}$ & $2.22 \pm 0.11^{\mathrm{e}}$ & $7.28 \pm 0.36^{b}$ \\
\hline 12.5 & 3.0 & 50 & $4.58 \pm 0.22^{\mathrm{a}}$ & $1.40 \pm 0.07^{\mathrm{c}}$ & $4.43 \pm 0.17^{c}$ & $8.10 \pm 0.40^{a b}$ \\
\hline 25.0 & 3.0 & 50 & $3.91 \pm 0.19^{b}$ & $1.22 \pm 0.06^{\mathrm{c}}$ & $2.44 \pm 0.12^{\mathrm{d}}$ & $8.12 \pm 0.42^{a b}$ \\
\hline 0 & 3.0 & 100 & $2.77 \pm 0.14^{c}$ & $0.63 \pm 0.03^{\mathrm{d}}$ & $4.54 \pm 0.21^{b}$ & $8.82 \pm 0.44^{\mathrm{ab}}$ \\
\hline 6.25 & 3.0 & 100 & $2.62 \pm 0.13^{c}$ & $0.49 \pm 0.02^{c}$ & $4.73 \pm 0.23^{\mathrm{ab}}$ & $8.84 \pm 0.40^{\mathrm{ab}}$ \\
\hline 12.5 & 3.0 & 100 & $2.54 \pm 0.12^{\mathrm{c}(1)}$ & $0.44 \pm 0.02^{\mathrm{c}}$ & $4.51 \pm 0.22^{b}$ & $8.78 \pm 0.43^{a b}$ \\
\hline 25.0 & 3.0 & 100 & $\begin{array}{c}2.60 \pm 0.13^{c(2)} \\
p<0.00002\end{array}$ & $\begin{array}{c}0.57 \pm 0.03^{b} \\
p<0.0001\end{array}$ & $\begin{array}{c}5.03 \pm 0.25^{\mathrm{a}} \\
p<0.0002\end{array}$ & $\begin{array}{c}8.72 \pm 0.444^{\mathrm{ab}} \\
p<0.00002\end{array}$ \\
\hline
\end{tabular}




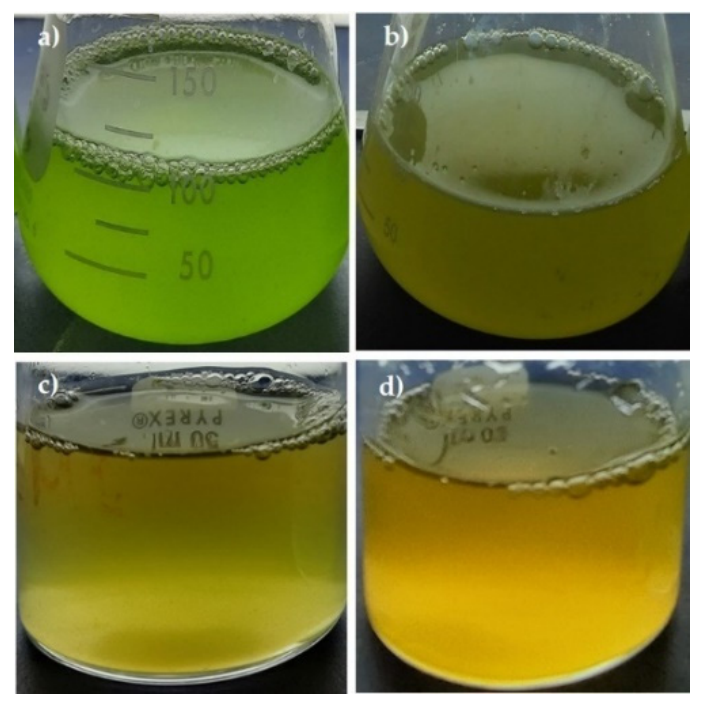

Figure 3. Cultures of D. salina on glycerol and controls. (a) IM, $1.5 \mathrm{M} \mathrm{NaCl}$ and $50 \mu \mathrm{mol} \mathrm{m}^{-2} \mathrm{~s}^{-1}$. (b) Gly, $3.0 \mathrm{M} \mathrm{NaCl}$ and $50 \mu \mathrm{mol}$ photons $\mathrm{m}^{-2} \mathrm{~s}^{-1}$. (c) IM, $1.5 \mathrm{M} \mathrm{NaCl}$ and $300 \mu \mathrm{mol}$ photons $\mathrm{m}^{-2}$ $\mathrm{s}^{-1}$. (d) Gly, $3.0 \mathrm{M} \mathrm{NaCl}$ and $300 \mu \mathrm{mol}$ photons $\mathrm{m}^{-2} \mathrm{~s}^{-1}$. The images were captured on the seventh day of culture when the pigments were analyzed. $(\mathbf{a}, \mathbf{b})$ correspond to the original culture flasks, whereas $(\mathbf{c}, \mathbf{d})$ are recipients only used for photography.

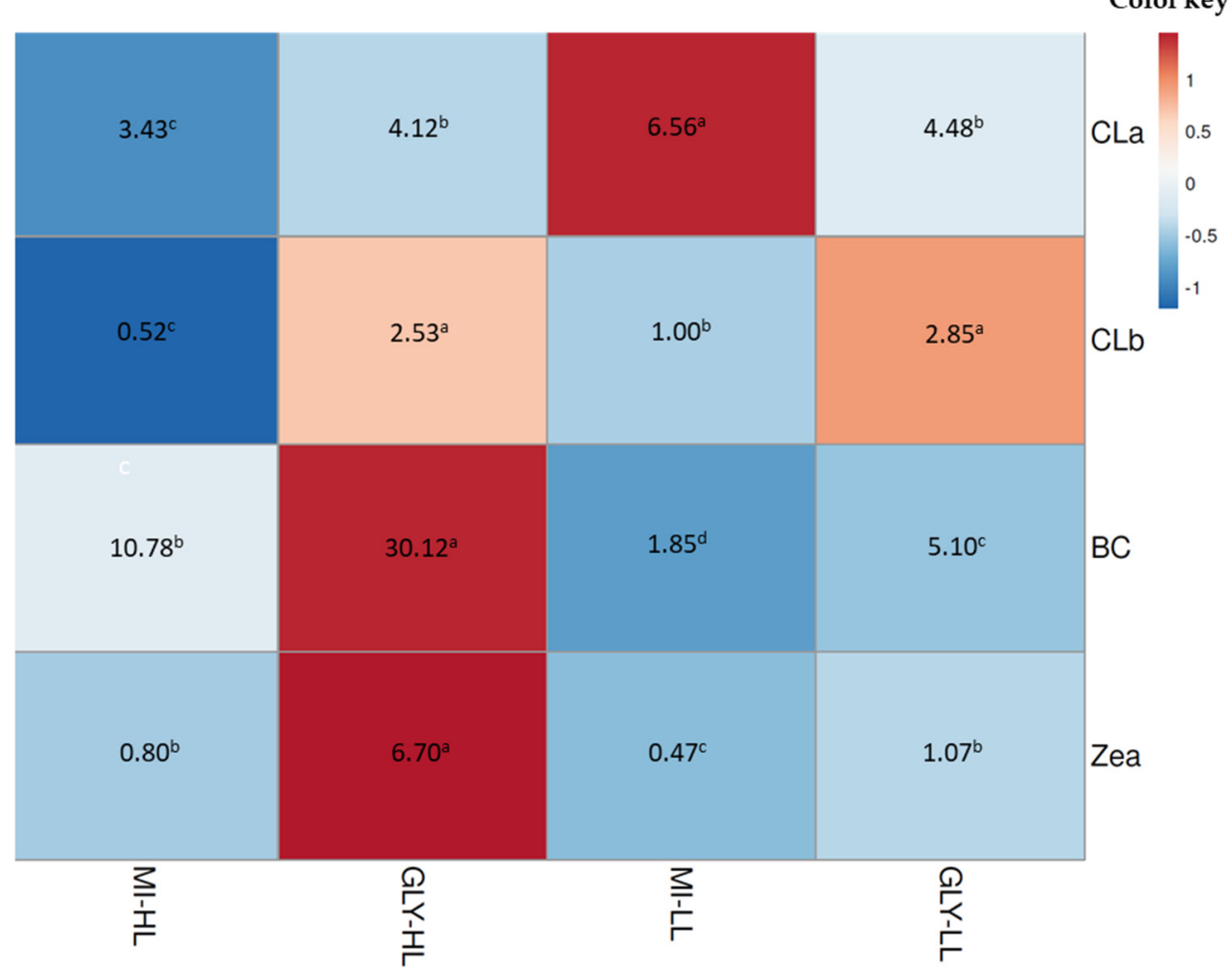

Figure 4. Heat map colors correspond to lower (blue) and higher (red) abundance for the main pigments of $D$. salina cultured under mixotrophic conditions. The real concentrations of pigments (pg cell ${ }^{-1}$ ) are in the heat map figure. MI-HL and Gly-HL correspond to the inorganic medium and glycerol exposed to $300 \mu \mathrm{mol}$ photons $\mathrm{m}^{-2} \mathrm{~s}^{-1}$, respectively. MI-LL and Gly-LL correspond to the inorganic medium and glycerol exposed to $50 \mu \mathrm{mol}$ photons $\mathrm{m}^{-2} \mathrm{~s}^{-1}$, respectively. Pigments (CLa: chlorophyll $a, \mathrm{CLb}$ : chlorophyll $b, \mathrm{BC}$ : $\beta$-carotene, Zea: zeaxanthin) were separated and identified by HPLC. Different letters in the same row are significantly different between pigment content for each treatment. 
Another set of experiments was developed to rule out whether the effect of glycerol by $D$. salina is dependent on change in salinity (1.5 to $3.0 \mathrm{M}$, non-isosmotic salinity) and not of the saline adaptation ( $3 \mathrm{M}$, isosmotic salinity). The microalga $D$. salina on $3 \mathrm{M}$ isosmotic salinity exhibited intermediate cell growth. Chl $a, \mathrm{Chl} b$, and BCar concentrations of microalgal cells exposed to this isosmotic salinity were lower than those obtained with non-isosmotic salinity, $3 \mathrm{M}$ (Tables 2 and 3). The culture $\mathrm{pH}$ under isosmotic salinity was maintained to be slightly acidic compared to the slightly basic $\mathrm{pH}$ of the microalgal culture under non-isosmotic salinity.

Table 3. Cell density, $\mathrm{Chl} a, \mathrm{Chl} b$, BCar, and culture $\mathrm{pH}$ of $D$. salina grown under $12.5 \mathrm{mM}$ Gly and IM control. Isosmotic salinity for growth and light intensity were $3.0 \mathrm{M} \mathrm{NaCl}$ and $50 \mu \mathrm{mol}$ photons $\mathrm{m}^{-2} \mathrm{~s}^{-1}$, respectively. The initial $\mathrm{pH}$ range was 6.20-6.35, and the final $\mathrm{pH}$ corresponds to the $7 \mathrm{th}$ day of cultivation. Values in the same columns with different superscript are significantly different.

\begin{tabular}{|c|c|c|c|c|c|}
\hline Culture Medium & $\begin{array}{l}\text { Cell Density } \\
\left(\mathrm{mL}^{-1} \times 10^{6}\right)\end{array}$ & $\begin{array}{c}\text { Chl } a \\
(\text { pg cell } \\
-1)\end{array}$ & $\begin{array}{c}\mathrm{Chl} b \\
\left(\mathrm{pg} \text { cell }^{-1}\right)\end{array}$ & $\begin{array}{c}\text { BCar } \\
\left(\mathrm{pg} \mathrm{cell}^{-1}\right)\end{array}$ & Final pH \\
\hline IM & $0.82 \pm 0.07^{a}$ & $1.02 \pm 0.09^{a}$ & $0.15 \pm 0.01^{b}$ & $2.39 \pm 0.22^{a}$ & $7.85 \pm 0.32^{a}$ \\
\hline $\begin{array}{c}\mathrm{IM}+12.5 \mathrm{mM} \text { Gly } \\
p \text {-value }\end{array}$ & $\begin{array}{c}0.98 \pm 0.09^{a} \\
p>0.070\end{array}$ & $\begin{array}{c}1.05 \pm 0.09^{\mathrm{a}} \\
p>0.712\end{array}$ & $\begin{array}{c}0.57 \pm 0.05^{a} \\
p<0.000\end{array}$ & $\begin{array}{c}2.24 \pm 0.20^{a} \\
p>0.426\end{array}$ & $\begin{array}{c}6.52 \pm 0.09 \mathrm{~b} \\
p<0.001\end{array}$ \\
\hline
\end{tabular}

\subsection{Extracellular and Intracellular Glycerol of D. salina}

Another group of experiments was carried out in order to know the dynamics of uptake of glycerol by D. salina. A continuous and substantial decrease in the extracellular glycerol of $D$. salina is observed with $3.0 \mathrm{M}$ salinity compared to $1.5 \mathrm{M}$ (Figure $5 \mathrm{~b}$ ). At the same time, a tiny amount of intracellular glycerol was observed throughout the microalgal culture at 1.5 and 3.0 M saline condition (Figure $5 \mathrm{~d}$ ). Lower values of extracellular (Figure 5a) and intracellular (Figure 5c) glycerol were observed in the inorganic medium without glycerol for both saline conditions. From these results, the uptake of glycerol from the medium by D. salina was preliminarily demonstrated.

\subsection{PSII Activity from D. salina Cultivated on Glycerol}

The maximum quantum efficiency Fv/Fm may be used to screen stressful or beneficial of organic substrates for the photosynthetic efficiency of $D$. salina under the mixotrophic growth conditions. In this work, the PSII activity of D. salina cultivated on glycerol is affected by the salinity level (Figure $6 \mathrm{a}, \mathrm{c}$ ). The Fv/Fm of D. salina cells cultivated on the optimized conditions of glycerol and light is greater for salinity $3 \mathrm{M}$ than $1.5 \mathrm{M}$, but these are less than photoautotrophic cultures (Figure 6a,c). Microalgal cultures under glycerol and DCMU at 1.5 and $3 \mathrm{M} \mathrm{NaCl}$ showed a notable drop in $\mathrm{Fv} / \mathrm{Fm}$ of D. salina cells for both salinities (Figure 6b,d). Furthermore, the different glycerol cultures and IM exposed to DCMU did not show microalgal growth.
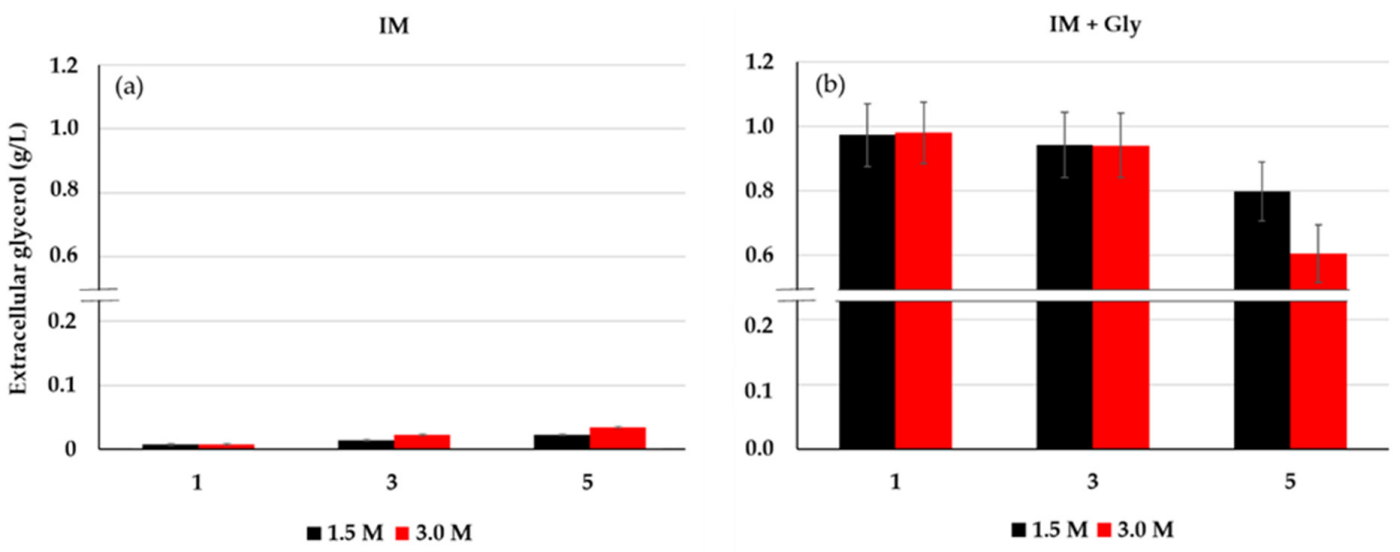

Figure 5. Cont. 
IM

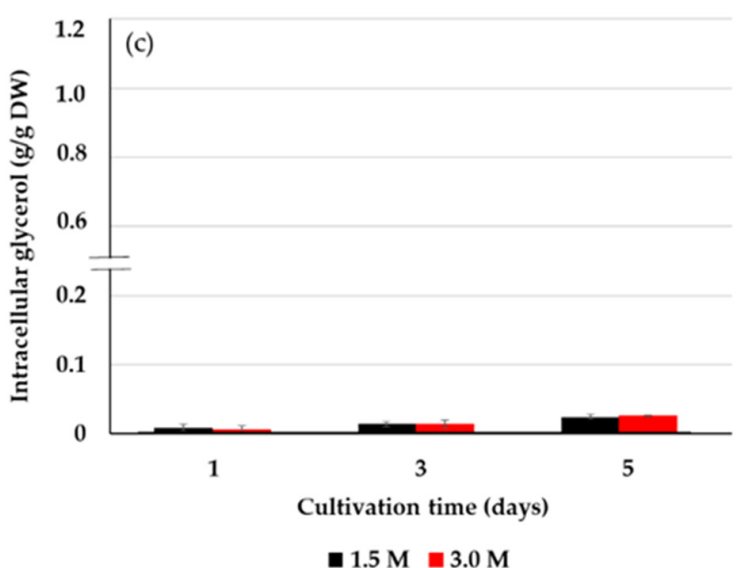

$\mathrm{IM}+$ Gly

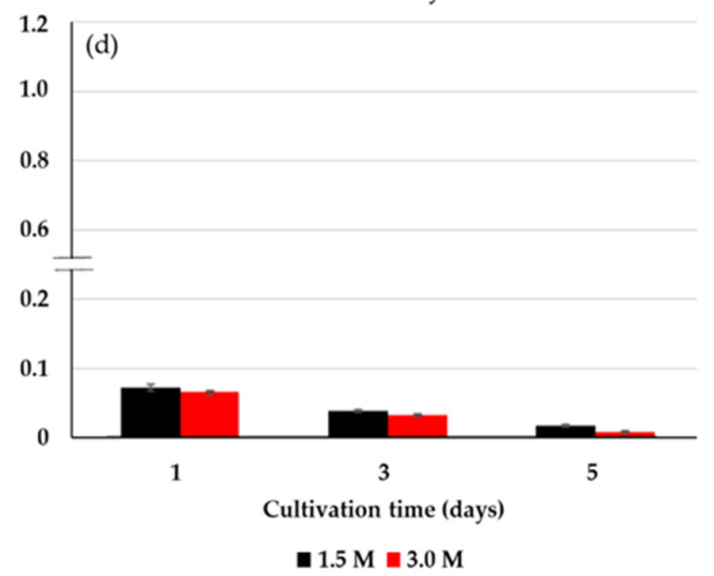

Figure 5. Extracellular glycerol from IM (a) and IM + Gly (b) and intracellular glycerol from IM (c) and IM + Gly (d) in D. salina cultivated on $12.5 \mathrm{mM}$ glycerol. Salinities: 1.5 and $3.0 \mathrm{M} \mathrm{NaCl}$. Intracellular glycerol concentrations were normalized to dry cell weight (DW). Values correspond to the mean \pm standard deviation of three replicates.
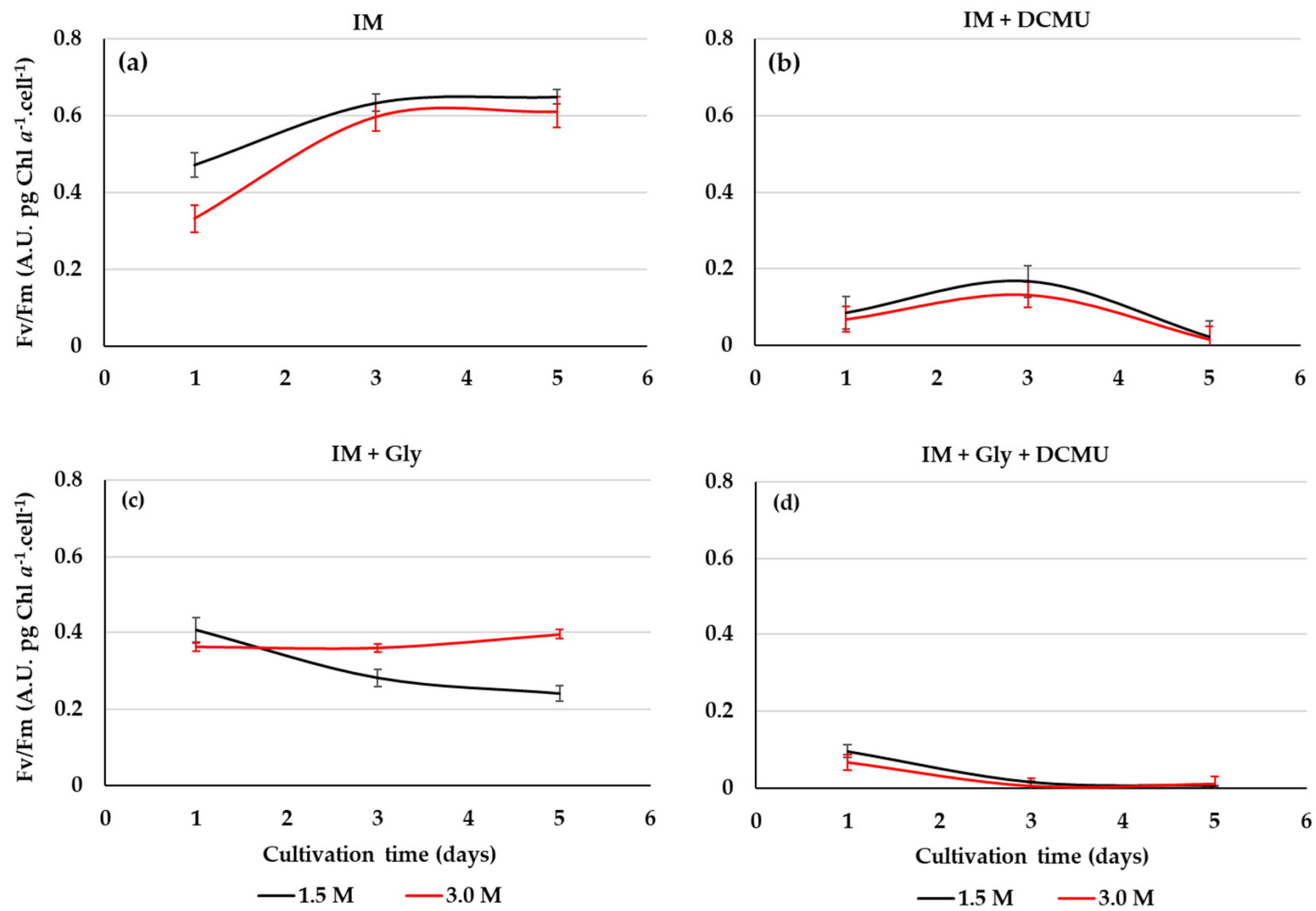

$-1.5 \mathrm{M}-3.0 \mathrm{M}$

Figure 6. Photosynthetic efficiency $(\mathrm{Fv} / \mathrm{Fm})$ of $D$. salina cultivated at different conditions: IM (a), IM + DCMU (b), $\mathrm{IM}+12.5 \mathrm{mM}$ Gly (c), and IM + 12.5 mM Gly + DCMU (d). Culture salinities: 1.5 and $3.0 \mathrm{M} \mathrm{NaCl}$. Values correspond to the mean \pm standard deviation of three replicates.

\section{Discussion}

In this study, the combined effect of glycerol level, light intensity, and salinity was assessed in order to optimize the mixotrophic culture conditions of D. salina. Our main aim was to contribute to develop a simple mixotrophic strategy to increase biomass and 
$\beta$-carotene production of this halophilic chlorophyte based exclusively on the optimization of the mixotrophic culture conditions with a non-fermentative organic carbon substrate, viz., glycerol. The proper growth of $D$. salina under low doses of glycerol is indicative of the efficient diffusion, active transport, or both of this substrate through the cell membranes. At higher concentrations, the glycerol could have an inhibitory effect on the growth and productivity of D. salina as reported [20]. Even high levels of glycerol may change the chloroplast ultrastructure, which reduces the excitation energy in PSII and decreases the photosynthetic activity and chlorophyll content [31]. Decreased concentrations of $D$. salina $\mathrm{Chl} a, \mathrm{Chl} b$, and $\beta$-Car in glycerol compared to photoautotrophic cultures (Control) may indicate that heterotrophic and myxotrophic culture conditions are progressing (Figure 5), as reported in Chlorella sorokiniana UTEX 1230 [32] and 1602 [33], respectively. These variations may respond to transition imbalances between photoautotrophy and heterotrophy, which cannot be discarded according to the experimental mixotrophic growth conditions, as recently reported [34,35]. Moreover, some organic substrates can change the $\mathrm{pH}$ of the medium and other properties such as viscosity, osmotic pressure, and gas-liquid transfer coefficient [36]. The $\mathrm{pH}$ close to neutral obtained from the microalgal mixotrophy assayed, may be demonstrative of a balanced system between photosynthesis $\left(\mathrm{CO}_{2}\right.$ consumed and $\mathrm{O}_{2}$ released) and respiration $\left(\mathrm{O}_{2}\right.$ consumed and $\mathrm{CO}_{2}$ released) fated to the glycerol assimilation for this chlorophyte [34].

The best results of the mixotrophic growth of this alga were obtained from low doses of glycerol $(12.5 \mathrm{mM})$ and non-isosmotic salinity $(3 \mathrm{M} \mathrm{NaCl})$, whose interaction stimulates the uptake of glycerol by the microalgal cells [37]. Concerning light intensity, better results were achieved with $50 \mu \mathrm{mol}$ photons $\mathrm{m}^{-2} \mathrm{~s}^{-1}$, which demonstrated that glycerol has broad performance under dim light in microalgae [38], and happened when D. salina was grown in mixotrophic conditions. Regarding to salinity, this green alga can grow in a range from $0.05 \mathrm{M}$ to $5.5 \mathrm{M} \mathrm{NaCl}$ [25], but show maximal growth performance at 1.5-3.0 $\mathrm{M} \mathrm{NaCl}$ [29]. Compared to cultures at $1.5 \mathrm{M} \mathrm{NaCl}, D$. salina grown at $3.0 \mathrm{M} \mathrm{NaCl}$ favors higher growth and synthesis of $\beta$-carotene in this alga on glycerol due to its antioxidant ability [29]. The high cell density obtained at usual promoting salinities for the growth of $D$. salina demonstrated that exogenous glycerol might play a nutritional role in this alga besides its well-known osmoregulatory role. This advantage is supported by its lower energy cost for cell metabolism compared to the assimilation of endogenous glycerol from photosynthesis or starch degradation [39]. The conversion of glycerol into glyceraldehyde 3-phosphate (G3P) allows for the binding to precursors associated with the carbon metabolic pathways of photosynthesis and respiration (phosphoenolpyruvate or pyruvate) that can affect cell growth and the synthesis of cellular metabolites [40,41]. In the optimized conditions of this work, chlorophyll $a$ level ( $4.58 \mathrm{pg}$. cell $\left.{ }^{-1}\right)$ was lower than the level of $11 \mathrm{pg}^{-1}$ cell $^{-1}$ obtained from $D$. salina cultures with glycerol [20]. However, initial $\beta$-carotene levels $\left(4.43\right.$ pg. cel $\left.{ }^{-1}\right)$ in this study were higher than $\beta$-carotene $\left(0.8 \mathrm{pg} \mathrm{cell}^{-1}\right)$ reported in this same work. Unlike the current knowledge on the mixotrophy of $D$. salina with glycerol, which is dominated by the photoautotrophic component, the optimized conditions of this work could induce glycerol balanced mixotrophy with codominance of both pigments.

In comparison to the straightforward mixotrophic production of biomass and $\beta$ carotene with different organic carbon substrates (glucose, acetate, and glycerol), our optimized cultivation condition with glycerol enhances suitable and productive balance between growth and carotenoids in this halophilic microalga (Table 4). In most initiatives on mixotrophic cultures $[12,13,20]$, only microalgal growth is enhanced, but $\beta$-carotene concentration remains low. Unlike our work, most of the reported microalgal cultures with higher growth or pigment levels $[10,12,13,20]$ are due to additional environmental and nutritional conditions that different authors carry out (e.g., higher substrate concentration, inoculum size, and high light intensity, longer cultivation periods, addition of other nutrients, and agitation or aeration systems), which affect microalgal production costs. Our approach seeks to develop a simple, practical, and inexpensive mixotrophic system. As a C3 molecule, glycerol can integrate into photoautotrophic and photoheterotrophic 
metabolism, but an efficient metabolic fit for its assimilation slightly favors photosynthesis over respiration that could be undergoing in this alga.

Table 4. Comparison of yield parameters of $D$. salina grown in glucose and glycerol from the literature and in the best experimental conditions in this work.

\begin{tabular}{cccc}
\hline Organic Carbon Substrate & $\mathbf{Y}_{\mathbf{x} / \mathbf{s}}\left(\mathbf{g ~ g}^{-\mathbf{1}}\right)$ & $\mathbf{Y}_{\mathbf{p} / \mathbf{s}}\left(\mathbf{m g ~ g}^{-\mathbf{1}}\right)$ & Reference \\
\hline Glucose & - & $8.91 \pm 0.06$ & {$[11]$} \\
Glycerol & $2.50 \pm 0.08$ & $1.16 \pm 0.02$ & {$[20]$} \\
& $2.33 \pm 0.03$ & $43.5 \pm 0.08$ & In this work \\
\hline
\end{tabular}

In our case, the photosynthetic reactions in D. salina were able to continue producing chlorophyllian pigments, energy, $\mathrm{CO}_{2}$ fixation, and even the incorporated carbon from glycerol could have been used to synthesize compounds not directly involved with cellular respiration (e. g., amino acids synthesis) [42]. Moreover, since the oxidative metabolism of the organic substrate is operating simultaneously in mixotrophy, a part of C-glycerol may switch to the tricarboxylic acid (TCA) cycle, where citrate intermediates are expressed at the gene level to induce respiration via the alternative mitochondrial pathway [43]. In principle, this mechanism may facilitate the massive synthesis of carotenoids [43] as the increase in $\beta$-carotene observed in D. salina. (Table 2).

The slightly basic $\mathrm{pH}$ values with glycerol are quite different from the sharp values of acidity and basicity obtained with glucose and acetate, respectively (data no shown). The mixotrophic growth of D. salina with $12.5 \mathrm{mM}$ glycerol, 3.0 M non-isosmotic salinity, and $50 \mu \mathrm{mol}$ photons $\mathrm{m}^{-2} \mathrm{~s}^{-1}$ light intensity suggests a balance in the following conditions: $\mathrm{CO}_{2} / \mathrm{O}_{2}$ gases, photosynthesis and respiration, and $\mathrm{pH}$ [34] during organic and inorganic carbon metabolism. Lastly, the highest microalgal productivity obtained under a selfbalanced culture $\mathrm{pH}$ could provide comparative advantages of mixotrophic cultures with glycerol compared to other organic substrates (e.g., glucose and acetate) for the massive and commercial production of this microalga.

In the case of $D$. tertiolecta cultivated under non-isosmotic conditions $(0.5$ to $4 \mathrm{mM}$ $\mathrm{NaCl})$, unlike the low assimilation rates of $5 \mathrm{mM}$ glycerol $\left(0.78 \mathrm{pg}\right.$ glycerol cell ${ }^{-1} \mathrm{~min}^{-1}$ for $5 \mathrm{~min})$ under isosmotic conditions $(0.5 \mathrm{mM} \mathrm{NaCl})$, this alga could assimilate the substrate at a rate of $3.14 \mathrm{pg}$ glycerol cell ${ }^{-1} \mathrm{~min}^{-1}$ for $15 \mathrm{~min}$ [37]. This phenomenon could also be occurring in our cultures with $D$. salina, where the cells grown under non-isosmotic salinity are receiving slight salt stress. This fact may trigger an osmoregulation process synthesizing the enzyme machinery involved with the uptake and assimilation of exogenous glycerol, fated to energy and carbon for osmotic regulation, growth, and cell pigments. Glycerol assimilation is species dependent; hence, some microalgae exhibit high growth in inorganic media supplemented with glycerol, while other species remain unaffected [44]. Unlike chlorophyte, photoheterotroph Dactylococcus dissociatus MT1 can totally consume the initial concentration of $6 \mathrm{mM}$ of glycerol within $24 \mathrm{~h}$ [31]. According to our results, chlorophyte photoautotroph $D$. salina slowly and progressively consumes glycerol throughout the culture, and possibly according to its nutritional and osmoregulatory needs. Likewise, although the plasmatic membrane of $D$. salina is several orders of magnitude less permeable to glycerol osmolyte, the presence of this compound in the controls of our experiments may suggest that the leakage of glycerol through these membranes may be much more widely distributed than just the release of glycerol by death and cell lysis [45].

The entire fate of incorporated glycerol by D. salina is still unknown. In our work, the gradual increase in extracellular glycerol content was observed through the IM medium (5a), and increase and decrease in the glycerol of D. salina in the IM + Gly medium. We hypothesized that these fluctuations may obey to the maintenance of glycerol homeostasis by the microalgal cells. Regarding to the large difference between glycerol uptake and glycerol assimilated by cells for their osmoregulation, much glycerol is metabolized (through diffusion, active transport, or both) and incorporated into the networks and pathways involved 
in the production of biomass, $\beta$-carotene, and carotenogenesis in D. salina. However, further experiments would be required to confirm these assertions.

The maximum quantum efficiency $\mathrm{Fv} / \mathrm{Fm}$ is an extremely sensitive, non-invasive index to assess the wellness of the microalgae photosynthetic apparatus via the photochemical efficiency of the PSII in response to energy metabolism and the interaction between carbon and nutrient assimilation [32,46]. Fv / Fm values obtained with glycerol $(0.435$ on average) were lower than those obtained in photoautotrophic cultures (IM), because the incorporation of this substrate linked to salinity could be generating different degrees of stress to the photosystems of $D$. salina. Contrary to the isosmotic condition $(1.5 \mathrm{M})$, the non-isosmotic salinity $(3 \mathrm{M})$ induces to the highest $\mathrm{Fv} / \mathrm{Fm}$ of $D$. salina cells grown on this substrate under mixotrophy. Indeed, an increase in photosynthetic activity coupled to the use of glycerol for respiration could be produced by these saline changes as reported for other stressors (e.g., high light) [47].

A remarkable decrease in the Fv/Fmax index was registered when D. salina was cultured with glycerol and DCMU, reflecting a disruption in the energetic status of the photosynthetic intermediaries across the damage in PSII reaction centers from this chlorophyte during the combined action of photoautotrophy and mixotrophy. In some way, the exerted action by photosynthesis and glycerol metabolism allow to allocate carbon toward growth and metabolites synthesis [48]. In this mixotrophic process, energy-rich molecules such as G3P and dihydroxyacetone phosphate (DHAP) are generated from glycerol. These C3 molecules transform into pyruvate, which, in turn, is decarboxylated to convert into acetyl-CoA [49]. In microalgal mixotrophy, biomass (energy from TCA cycle) and metabolites (e.g., pigments and fatty acid) synthesis pathways compete for this key thioester substrate [50]. In this study, optimized mixotrophy conditions by glycerol suggest that acetyl CoA or another intermediate is appropriately channeled for mixotrophic biosynthetic processes that stimulate growth and $\beta$-carotene in $D$. salina. This is the first study that reveals an unknown role of glycerol in addition to that involved in osmoregulation, mainly the simultaneous and improved production of cellular biomass and pigments of $D$. salina, especially $\beta$-carotene. This metabolic pattern occurs when the particular mixotrophic conditions exerted by glycerol are optimized, particularly through a suitable and selective combination of salinity and light. The photoautotrophic cultures, such as in the case of Dunaliella, are characterized per se by the low capacity of microalgal photosystems to capture light energy, as well as inorganic carbon limitation in extreme and hypersaline environments and media. In contrast, the mixotrophic culture of $D$. salina when regulated by sodium chloride and glycerol may become a new culture strategy to increase $D$. salina production yields. This microalga cultured on glycerol exhibited maxima yields, viz., yield biomass/substrate $(\mathrm{Yx} / \mathrm{s})$, and yield product ( $\beta$-carotene)/substrate $(\mathrm{Yp} / \mathrm{s})$ (Table 4). The bioproduction processes and parameters of microalgae and particularly of Dunaliella salina under mixotrophic growth conditions, still require of specific optimization approaches. Our mixotrophic cultures with glycerol did not receive $\mathrm{CO}_{2}$, any other source of nutrients (only the inorganic culture medium), or continuous mechanical agitation. In mixotrophic cultures, microalgal growth is affected by $\mathrm{CO}_{2} / \mathrm{O}_{2}$ availability from agitation [51]. Despite this, our $\mathrm{Yx} / \mathrm{s}$ and $\mathrm{Yp} / \mathrm{s}$ ( $\beta$-carotene) results are superior to yields obtained by some reports on mixotrophic cultures in this species. (Table 4).

Microalgal cultures with the highest cellular growth (3.0 $\mathrm{M} \mathrm{NaCl}$ and Gly) progressively reach high levels of $\beta$-carotene, which occurred in cellular cultures after three days of being subjected to a high light level. In D. salina CCAP 19/30 cells, this effect was attributed to an increase in light intensity (50 to $200 \mu \mathrm{mol}$ photons $\mathrm{m}^{-2} \mathrm{~s}^{-1}$ ), which caused the stabilization of the photosynthetic apparatus and of the chlorophylls [47].

The increase in carotenoids ( $\beta$-carotene and zeaxanthin) is related to their protective action against oxidative stress such as hypersalinity and high light intensity [52]. The microalga Chlamydomonas acidophila grown on glycerol seems to enhance the $\beta$-carotene pathway compared to its photoautotrophic metabolism [53]. Under these conditions, the acetyl-CoA and NADPH production required to increase the $\beta$-carotene content should 
come from the energy excess of glycerol catabolism as reported in another microorganism [54]. In addition to the bioconversion of exogenous glycerol into key intermediates of general metabolism, it could have directly impacted the synthesis of carotenogenesis. The effect of high intensity light has been related with the transcriptional activation of carotenogenic genes in response to stimulation by phytohormones [55]. Our results, in accordance with recent reports on high growth rates and $\beta$-carotene content in $D$. salina MCCS-001, are associated with the effect of indole-3-acetic acid [56] that could be derived from exogenous glycerol [57], which may support our results in cellular performance.

In most cases of photoautotrophic and mixotrophic cultures of $D$. salina, cellular density can improve and the content of $\beta$-carotene remains low, and vice versa (Table 5 ). Our culture system is more suitable and efficient for the production of biomass and $\beta$ carotene in D. salina compared with the current literature. Sohrabi et al. [20] obtained biomass yields higher than ours; however, their cultivation conditions consisted of $2 \times$ concentrations for the glycerol and inocula compared to our experimental approach.

Until quite recently, it was generally believed that $D$. salina was an obligate photoautotroph. This assigned nutrition mode limited the development of the great potential of this model alga in many applications that remained unexplored and unexploited. Our results indicated that the synergy of photosynthesis and glycerol uptake under mixotrophic culture conditions induced higher yields of biomass and $\beta$-carotene when compared to the photoautrophic and heterotrophic metabolism of D. salina. In this research, glycerol, besides its main role in osmoregulation, plays a strategic role as a metabolic substrate particularly valuable for the profitable production of biomass and carotenoids, mainly $\beta$-carotene, at low cost, and opens new avenues for future applications inserting $D$. salina in the cost-effective production of various bioproducts, bioprocesses, and services. This approach makes mixotrophy in this alga advantageous in many marine, saline, and industrial production processes that are carried out in the presence of high concentrations of $\mathrm{NaCl}$. Particularly, the advantages of this mixotrophy initiative represent a particular interest in halophiles, such as D. salina, for biofuel production in coastal-marine wastewater treatment and bioremediation that, when coupled to the mixotrophic production of low-cost biomass and $\beta$-carotene, represent a profitable and affordable approaches leading to biorefineries. The production of high-value nutraceuticals, antioxidants, pro-vitamin $A$ production, food and feed pigments, and wastewater treatment and bioremediation can greatly benefit from this.

Table 5. Biomass and $\beta$-carotene of $D$. salina grown with various carbon substrates reported by the literature and in this work.

\begin{tabular}{cccc}
\hline Substrate & Biomass & $\beta$-Carotene & Reference \\
\hline Inorganic & $1.0-5.0 \times 10^{6}$ cells mL $^{-1}$ & $4-8 \mathrm{gg} \mathrm{cell}^{-1}$ & {$[58,59]$} \\
Glucose & $0.99 \mathrm{~g} \mathrm{~L}^{-1}$ & $8.03 \mathrm{mg} \mathrm{g}^{-1}$ & {$[12]$} \\
Acetate & $1.0-1.2 \times 10^{6} \mathrm{cells} \mathrm{mL}^{-1}$ & $<5 \mathrm{pg} \mathrm{cell}^{-1}$ & {$[13]$} \\
Glycerol & $1.0 \times 10^{6} \mathrm{cells} \mathrm{mL}^{-1}$ & $0.94 \mathrm{~g} \mathrm{cell}^{-1}$ & {$[28]$} \\
& $4.0-5.0 \times 10^{6} \mathrm{cells} \mathrm{mL}^{-1}$ & $0.8-1.0 \mathrm{pg} \mathrm{cell}^{-1}$ & {$[20]$} \\
& $2.15 \times 10^{6} \mathrm{cells} \mathrm{mL}^{-1}$ & $30 \mathrm{pg} \mathrm{cell}^{-1}$ & In this work \\
& $\left(2.0 \mathrm{~g} \mathrm{~L}^{-1}\right)$ & $\left(50 \mathrm{mg} \mathrm{g}^{-1}\right)$ & \\
\hline
\end{tabular}

\section{Materials and Methods}

\subsection{Strain and Culture Conditions}

The Mexican strain, Dunaliella salina BC02 used in this work, was obtained from the microalgae collection of the Department of Marine Biotechnology from CICESE (Ensenada, Mexico). Microalgal cells were grown in $250 \mathrm{~mL}$ Erlenmeyer flasks containing $100 \mathrm{~mL}$ of inorganic culture medium (IM) designed for Dunaliella [60]. The inoculated culture flasks were placed in an environmental chamber built ex professo both to maintain the temperature of the culture $\left(22 \pm 02{ }^{\circ} \mathrm{C}\right)$ [61] and to manage the different light intensities with 40 watts cool white fluorescent lamps, unless otherwise indicated. Photoautotrophic 
pre-cultures were grown in IM at $50 \mu \mathrm{mol}$ photons $\mathrm{m}^{-2} \mathrm{~s}^{-1}$ light, $1.5 \mathrm{M}$ salinity, $\mathrm{pH}$ in the 7.5-8.0 range, and without aeration. Once at exponential phase, inocula precultures $(10 \%)$ were set up at $0.1 \times 10^{6} \mathrm{cells} \mathrm{ml}^{-1}$ for later inoculate each mixotrophic culture for $D$. salina with glycerol (Gly) and the controls.

\subsection{Mixotrophic Growth Conditions Set Up}

To improve the $\beta$-carotene and microalgal growth, the proposed inorganic medium was optimized to the most suitable conditions of glycerol, light intensity, and salinity for the mixotrophic culture. The proper concentrations of 1.5 and $3.0 \mathrm{M} \mathrm{NaCl}$ used in the experimental units served to assess changes in cell growth by salinity according to Farhat et al. [29]. The light intensities were set according to Sforza et al. [62] and were set up as follows: heterotrophy in light $\left(10 \mu \mathrm{mol}\right.$ photons $\left.\mathrm{m}^{-2} \mathrm{~s}^{-1}\right)$, mixotrophy $(50 \mu \mathrm{mol}$ photons $\left.\mathrm{m}^{-2} \mathrm{~s}^{-1}\right)$, photoautotrophy $\left(100 \mu \mathrm{mol}\right.$ photons $\left.\mathrm{m}^{-2} \mathrm{~s}^{-1}\right)$, and carotenogenic light $\left(300 \mu \mathrm{mol}\right.$ photons $\left.\mathrm{m}^{-2} \mathrm{~s}^{-1}\right)$ were measured with a light meter (VWR, Catalog Number 21800-014). A Hanna meter (HI98130) recorded the influence of $\mathrm{pH}$ on the cell growth in glycerol. The microalgal cultures were gently hand-shaken (two times daily for $2 \mathrm{~min}$ ) [14], and $\mathrm{CO}_{2}$ unfed. The mixotrophic growth of D. salina was compared only to the photoautotrophic control, because no cellular growth on glycerol was observed under heterotrophic conditions without light. For mixotrophic experiments, glycerol (Sigma Aldrich, Mexico) was added in the inorganic growth medium (IM) to give the following concentrations: $3.12,6.25,12.5,25,50$, and $100 \mathrm{mM}$, respectively.

\subsection{Cell Growth and Dry Cell Weight}

The cellular density of $D$. salina was evaluated by direct counting for each experimental treatment and control by the Neubauer chamber and an Olympus compound microscope model BX60. With the obtained data, a growth curve was made, which exponential phase was selected, in order to calculate the specific growth rate $(\mu)$ as suggested [63] from Equation (1):

$$
\mu=\frac{\ln \mathrm{N} 1-\ln \mathrm{N} 0}{\mathrm{~T} 1-\mathrm{T} 0}
$$

where $\mathrm{N} 1$ and $\mathrm{N} 0$ are the final and initial cell density (cells number per $\mathrm{mL}$ ), respectively; $\mathrm{T} 1$ and $\mathrm{T} 0$ are the final and initial cultivation time (days).

The initial and final biomass were determined gravimetrically to calculate the dry cell weight as recommended [64]. Aliquots of $10 \mathrm{~mL}$ of microalgal culture at each experimental condition were filtered through preweighed, and precombusted $\left(450{ }^{\circ} \mathrm{C}\right.$ for two hours) glass-fiber filters (Whatman GF/F, $47 \mathrm{~mm}$, pore size $0.7 \mu \mathrm{m}$ ) using a vacuum pump (at 35 to $55 \mathrm{~mm} \mathrm{Hg}$ ). Then, the filters were washed three times, with $20 \mathrm{~mL} 0.5 \mathrm{M}$ ammonium formate to remove the remaining salt. Finally, filters were dried and weighted to obtain dry biomass at constant weight.

\subsection{Pigment Content}

\subsubsection{Spectrophotometric Determination}

For pigment extraction, $2 \mathrm{~mL}$ of microalgal suspension were placed in microtubes and centrifuged at $5000 \mathrm{rpm}$ for $10 \mathrm{~min}$ at $4{ }^{\circ} \mathrm{C}$ in an Eppendorf refrigerate centrifuge. Then, the culture medium was removed, and $1 \mathrm{~mL}$ pure acetone was added to dissolve the residual pellet [65]. The samples were vortexed and stored at $4{ }^{\circ} \mathrm{C}$ in the dark for at least $5 \mathrm{~h}$. Afterward, the homogenates were filtered onto $0.2 \mu \mathrm{m}$ filters (Whatman) and the extracts were immediately used for spectrophotometric measurements. The analysis of chlorophyll $a(\mathrm{Chl} a)$, chlorophyll $b(\mathrm{Chl} b)$, and $\beta$-carotene (BCar) was carried out in a $2 \mathrm{~mL}$ quartz cuvette by a Hach DR 5000 spectrophotometer. The scan spectra from 200 to $700 \mathrm{~nm}$, with a resolution of $1.0 \mathrm{~nm}$, were digitally recorded and processed. The Equations 
(2)-(4) describe the calculated pigment concentrations as previously reported [66]: Later, these values were standardized using the cell concentration ( $\mathrm{pg} \mathrm{cell}^{-1}$ ) of each treatment.

$$
\begin{gathered}
\text { Chl } a=11.75 A 662-2.35 A 645\left(\text { in } \mu \mathrm{g} \mathrm{mL} \text { of extract }{ }^{-1}\right) \\
\text { Chl } b=18.61 A 645-3.96 A 662\left(\text { in } \mu \mathrm{g} \mathrm{mL} \mathrm{of} \mathrm{extract}{ }^{-1}\right) \\
\text { BCar }=\frac{1000 A 470-2.27 \mathrm{Chl} a-81.4 \mathrm{Chl} b}{227}\left(\text { in } \mu \mathrm{g} \mathrm{mL} \mathrm{of} \mathrm{extract}{ }^{-1}\right)
\end{gathered}
$$

\subsubsection{HPLC Analysis}

Pigment profile analysis and the quantitative estimation of chlorophylls and carotenoids were carried out using an Agilent 1260 HPLC system equipped with a Zorbax XDB-C8 reversed phase column $\left(4.6 \times 150 \mathrm{~mm}, 3.5 \mu \mathrm{m}\right.$ pore size and $1 \mathrm{~mL} \mathrm{~min}^{-1}$ flow-rate $[67,68]$. Pigments were extracted from $1 \mathrm{~mL}$ of microalgal culture using $1 \mathrm{~mL}$ of $100 \%$ acetone. The samples were placed at $-20^{\circ} \mathrm{C}$ overnight in darkness [68]. Prior to the HPLC analysis, samples were centrifuged at $5000 \mathrm{rpm}$ for $5 \mathrm{~min}$ at $4{ }^{\circ} \mathrm{C}$. The supernatant was filtered with $0.22 \mu \mathrm{m}$ filter into amber vials. The pigments extracted in acetone were directly injected to the HPLC column. The column temperature was set at $60^{\circ} \mathrm{C}$ and the injection volume was $20 \mu \mathrm{L}$. Mobile phase: solvent A, methanol and $28 \mathrm{mM}$ tetrabutyl ammonium acetate, 70:30 (v:v); solvent B, methanol. Solvent delivery gradient was in $\%$ B (min): $5 \%, 0 \mathrm{~min} ; 5 \%$, $5 \mathrm{~min} ; 95 \%, 22 \mathrm{~min} ; 95 \%, 27 \mathrm{~min} ; 5 \%, 30 \mathrm{~min}$ as reported [67]. Pigments were eluted at a flow rate of $1 \mathrm{~mL} \mathrm{~min}^{-1}$ and detected at an absorbance range of $360-700 \mathrm{~nm}$, specifically at $436 \mathrm{~nm}$ to separate properly chlorophylls and carotenoids. The identification of the pigments was based on the comparison of the retention times of samples with those of pure standard pigments obtained from DHI Laboratory Products (Hørsholm, Denmark) as previously described [69].

\subsection{Extracellular and Intracellular Glycerol of D. salina}

Extra and intracellular glycerol was assayed enzymatically with a commercial glycerol determination kit (SKU, 12812, BioSystems Reagents \& Instruments, Barcelona, Spain). For sample preparation, $1 \mathrm{~mL}$ aliquots of microalgal culture were placed into microtubes to determine extracellular and total glycerol [70]. A set of tubes was directly centrifuged at $5000 \mathrm{rpm}$ for $15 \mathrm{~min}$ at $4{ }^{\circ} \mathrm{C}$ and the supernatants used to estimate extracellular glycerol according to manufacturer's specifications. Other tubes with microalgal culture were incubated for $10 \mathrm{~min}$ at $100{ }^{\circ} \mathrm{C}$. After, the homogenates were centrifuged and supernatants were used for total glycerol determination. Intracellular glycerol was calculated from the difference between total glycerol and extracellular glycerol. Glycerol concentrations were normalized to dry cells weight.

\subsection{Photosynthetic Efficiency Measurement}

The Chl $a$ fluorescence index, represented by the equation: $\mathrm{Fv} / \mathrm{Fm}=(\mathrm{Fm}-\mathrm{F}) / \mathrm{Fm}$ [46] was applied to assess the changes in photosynthetic activity, viz., the maximum quantum efficiency of PSII in microalgal cells when exposed to glycerol. The Fv/Fm was determined on cell cultures of $D$. salina exposed to the best treatment $(12.5 \mathrm{mM}$ Gly, $50 \mu \mathrm{mol}$ photons $\mathrm{m}^{-2} \mathrm{~s}^{-1}$ and 3.0 M NaCl), DCMU (3-(3,4-dichlorophenyl)-1,1-dimethylurea), and controls, respectively. The registered fluorescence was carried out in samples previously adapted to dim light for $15 \mathrm{~min}$, at $25^{\circ} \mathrm{C}$, using a Pulse-amplitude modulated fluorometer (DUALPAM 100, Heinz Walz, Effeltrich, Germany). Triplicate measurements for each sample and five saturating pulses at intervals of $30 \mathrm{~s}$ were sufficient to obtain a stationary level of maximum fluorescence (Fm) of $D$. salina cells. The fluorescence signal was normalized to chlorophyll $a$ content of the microalgal cells as recommended [46]. To evaluate the changes on PSII activity by glycerol, intact cells of $D$. salina were exposed to $20 \mathrm{mM}$ DCMU [71]. 


\subsection{Yield Parameters}

Representative parameters of microalgal yield, such as: biomass/substrate yield $(\mathrm{Yx} / \mathrm{s})$ $\left(\mathrm{g} \mathrm{g}^{-1}\right)$ and $\beta$-carotene/substrate yield $(\mathrm{Yp} / \mathrm{s})\left(\mathrm{mg} \mathrm{g}^{-1}\right)$ were calculated from Equations (5) and (6) as proposed [72]. The biomass productivity was calculated at maximum microalgal growth (seventh day), as follows:

$$
\begin{gathered}
\mathrm{Yx} / \mathrm{s}=\frac{\text { Produced biomass }}{\text { Consumed substrate }} \\
\mathrm{Yp} / \mathrm{s}=\frac{\text { Produced (BCar) product }}{\text { Consumed substrate }}
\end{gathered}
$$

\subsection{Statistical Analysis}

All experimental designs accomplished the criteria of randomness to ensure regular and reproducible results as suggested [73]. The data correspond to the mean \pm standard deviation from three independent cultures. One-way analysis of variance (ANOVA) at $p$-value $<0.05$ was calculated to detect significant differences in microalgal growth and pigments under different concentrations of glycerol using the STATISTICA 12.0 program. A Tukey's test was applied to assess differences among treatments means. The combined effect among glycerol concentration, salinity, and light intensity on cell growth, pigments, and culture $\mathrm{pH}$ were pondered by a factorial ANOVA test.

\section{Conclusions}

The photosystems of D. salina can choose other options than obligate photoautotrophy, viz., facultative mixotrophy. This microalga possesses the physiometabolic and productive capacity to assimilate flexible and highly reduced organic substrates as glycerol under optimized culture conditions. This condition induced by glycerol, light, and salinity serve to maximize $\beta$-carotene accumulation without compromising the high biomass production through dichotomous role of glycerol in photosynthesis and respiration under mixotrophy. In particular, the uptake of glycerol by $D$. salina represents more energy and carbon to promote growth, carotenoid synthesis, and carotenogenesis. This optimized mixotrophic culture system could be expanded to transfer strains and substrates, and increase production yields in a low-cost and sustainable way. In this research, glycerol, besides its main role in osmoregulation, plays a strategic role as a metabolic substrate in this microalga, and is particularly valuable for the profitable and affordable production of biomass and carotenoids, mainly $\beta$-carotene. It also opens new avenues for future applications inserting D. salina in the cost-effective production of various bioproducts, bioprocesses, and services. The synergy of photosynthesis and glycerol metabolism makes mixotrophy in this alga advantageous in many marine, saline, and industrial production processes that are carried out in the presence of high concentrations of $\mathrm{NaCl}$. These advantages are of particular interest in halophiles, such as D. salina, for biofuel production in coastal-marine wastewater treatment and bioremediation that, when coupled to the mixotrophic production of biomass and B-carotene, represent profitable and affordable approaches. Particularly, this research may greatly impact the production of high-value nutraceuticals, antioxidants, pro-vitamin $A$ production, the concept of marine algal biofuels and biorefineries, and wastewater treatment and bioremediation.

Author Contributions: Investigation, W.C.-R. and J.d.J.P.-M.; methodology, E.G.-M.; writingoriginal draft, W.C.-R. and J.d.J.P.-M. All authors have read and agreed to the published version of the manuscript.

Funding: This research was funded by CICESE internal funding 682101. The APC was funded in part by CICESE funding number 682101.

Institutional Review Board Statement: Not applicable.

Informed Consent Statement: Not applicable. 
Data Availability Statement: The data presented in this study are available in article.

Conflicts of Interest: The authors declare no conflict of interest.

\section{References}

1. Cezare-Gomes, E.A.; Mejia-da-Silva, L.; Pérez-Mora, L.S.; Matsudo, M.; Ferreira-Camargo, L.; Singh, A.; Monteiro de Carvalho, J.C. Potential of microalgae carotenoids for industrial application. Appl. Biochem. Biotech. 2019, 188, 602-634. [CrossRef]

2. Wang, L.; Liu, Z.; Jiang, H.; Mao, X. Biotechnology advances in $\beta$-carotene production by microorganisms. Trends Food Sci. Technol. 2021, 111, 322-332. [CrossRef]

3. Mehariya, S.; Goswami, R.K.; Karthikeysan, O.P.; Verma, P. Microalgae for high-value products: A way towards green nutraceutical and pharmaceutical compounds. Chemosphere. 2021, 280, 130553. [CrossRef]

4. Molino, A.; Mehariya, S.; Di Sanzo, G.; Larocca, V.; Martino, M.; Leone, G.P.; Marino, T.; Chianese, S.; Balducchi, R.; Musmarra, D. Recent developments in supercritical fluid extraction of bioactive compounds from microalgae: Role of key parameters, technological achievements and challenges. J. $\mathrm{CO}_{2}$ Util. 2020, 36, 196-209. [CrossRef]

5. Ejike, E.C.C.; Collins, S.A.; Balasuriya, N.; Swanson, A.K.; Mason, B.; Udenigwe, C.C. Prospects of microalgae proteins in producing peptide-based functional foods for promoting cardiovascular health. Trends Food Sci. Technol. 2017, 59, 30-36. [CrossRef]

6. Monte, J.; Ribeiro, C.; Parreira, C.; Costa, L.; Brive, L.; Casal, S.; Brazinha, C.; Crespo, J.G. Biorefinery of Dunaliella salina: Sustainable recovery of carotenoids, polar lipids and glycerol. Bioresour. Technol. 2020, 297, 122509. [CrossRef]

7. Patel, A.K.; Singhania, R.R.; Sim, S.J.; Di Dong, C. Recent advancements in mixotrophic bioprocessing for production of high value microalgal products. Bioresour. Technol. 2021, 320, 124421. [CrossRef] [PubMed]

8. Poddar, N.; Sen, R.; Martin, G. Glycerol and nitrate utilisation by marine microalgae Nannochloropsis salina and Chlorella sp. and associated bacteria during mixotrophic and heterotrophic growth. Algal Res. 2018, 33, 298-309. [CrossRef]

9. Sun, H.; Zhao, W.; Mao, X.; Li, Y.; Wu, T.; Chen, F. High-value biomass from microalgae production platforms: Strategies and progress based on carbon metabolism and energy conversion. Biotechnol. Biofuels 2018, 11, 227. [CrossRef]

10. Chavoshi, Z.Z.; Shariati, M. Lipid production in Dunaliella salina under autotrophic, heterotrophic, and mixotrophic conditions. Biologia 2019, 74, 1579-1590. [CrossRef]

11. Gonabadi, E.; Samadlouie, H.R.; Zenoozian, M.S. Optimization of culture conditions for enhanced Dunaliella salina productions in mixotrophic culture. Prep. Biochem. Biotechnol. 2021. [CrossRef] [PubMed]

12. Morowvat, M.; Ghasemi, Y. Culture medium optimization for enhanced $\beta$-carotene and biomass production by Dunaliella salina in mixotrophic culture. Biocatal. Agric. Biotechnol. 2016, 7, 217-223. [CrossRef]

13. Mojaat, M.; Pruvost, J.; Foucault, A.; Legrand, J. Effect of organic carbon sources and $\mathrm{Fe}^{2+}$ ions on growth and $\beta$-carotene accumulation by Dunaliella salina. Biochem. Eng. J. 2008, 39, 177-184. [CrossRef]

14. Keerthi, S.; Koduru, U.; Sarma, N. A nutrient medium for development of cell dense inoculum in mixotrophic mode to seed mass culture units of Dunaliella salina. Algol. Stud. 2015, 147, 7-28. [CrossRef]

15. Liu, X.; Duan, S.; Li, A.; Xu, N.; Cai, Z.; Hu, Z. Effects of organic carbon sources on growth, photosynthesis, and respiration of Phaeodactylum tricornutum. J. Appl. Phycol. 2009, 21, 239-246. [CrossRef]

16. Kim, H.S.; Park, W.K.; Lee, B.; Seon, G.; Suh, W.I.; Moon, M.; Chang, Y.K. Optimization of heterotrophic cultivation of Chlorella sp. HS2 using screening, statistical assessment, and validation. Sci. Rep. 2019, 9, 19383. [CrossRef]

17. Chalima, A.; Oliver, L.; Fernández de Castro, L.; Karnaouri, A.; Dietrich, T.; Topakas, A. Utilization of Volatile Fatty Acids from Microalgae for the Production of High Added Value Compounds. Fermentation 2017, 3, 54. [CrossRef]

18. Baldisserotto, C.; Sabia, A.; Guerrini, A.; Demaria, S.; Maglie, M.; Ferroni, L.; Pancaldi, S. Mixotrophic cultivation of Thalassiosira pseudonana with pure and crude glycerol: Impact on lipid profile. Algal Res. 2021, 54, 102194. [CrossRef]

19. Rajendran, L.; Nagarajan, N.G.; Karuppan, M. Enhanced biomass and lutein production by mixotrophic cultivation of Scenedesmus sp. using crude glycerol in an airlift photobioreactor. Biochem. Eng. J. 2020, 161, 107684. [CrossRef]

20. Sohrabi, D.; Jazini, M.H.; Shariati, M. Mixotrophic cultivation of Dunaliella salina on crude glycerol obtained from calcinated fatty acid production process. Russ. J. Mar. Biol. 2019, 45, 470-480. [CrossRef]

21. Zhang, L.; Zhang, C.; Liu, J.; Yang, N. A strategy for stimulating astaxanthin and lipid production in Haematococcus pluvialis by exogenous glycerol application under low light. Algal Res. 2020, 46, 101779. [CrossRef]

22. Clomburg, J.M.; Gonzalez, R. Anaerobic fermentation of glycerol: A platform for renewable fuels and chemicals. Trends Biotechnol. 2013, 31, 20-28. [CrossRef]

23. Taghavi, N.; Robinson, G. Improving the optimum yield and growth of Chlamydomonas reinhardtii CC125 and CW15 using various carbon sources and growth regimes. Afr. J. Biotechnol. 2016, 15, 1083-1100.

24. Bindea, M.; Rusu, B.; Rusu, A.; Trif, M.; Leopold, L.F.; Dulf, F.; Vodnar, D.C. Valorification of crude glycerol for pure fractions of docosahexaenoic acid and $\beta$-carotene production by using Schizochytrium limacinum and Blakeslea trispora. Microb. Cell Fact. 2018, 17, 97. [CrossRef]

25. Borowitzka, M.; Borowitzka, L. Dunaliella. In Micro-Algal Biotechnology; Borowitzka, M., Borowitzka, L., Eds.; Cambridge University Press: New York, NY, USA, 1988; pp. 27-58.

26. Chen, H.; Jiang, J. Osmotic Responses of Dunaliella to the Changes of Salinity. J. Cell. Physiol. 2009, 219, 251-258. [CrossRef] 
27. D'Imporzano, G.; Salati, S.; Veronesi, D.; Scaglia, B.; Adani, F. Microalgae Mixotrophic Growth: Opportunity for Stream Depuration and Carbon Recovery. In Prospects and Challenges in Algal Biotechnology; Tripathi, B.N., Kumar, D., Eds.; Springer Nature: Singapore, 2017; pp. 141-177.

28. Suarez, G.; Romero, T.; Borowitzka, M. Cultivo de Dunaliella salina en medio orgánico. Boletín Cent. Investig. Biológicas Maracaibo 1999, 33, 211-225.

29. Farhat, N.; Rabhi, M.; Falleh, H.; Jouini, J.; Abdelly, C.; Smaoui, A. Optimization of salt concentrations for a higher carotenoid production in Dunaliella salina (chlorophyceae). J. Phycol. 2011, 47, 1072-1077. [CrossRef]

30. Guevara, M.; Lodeiros, C.; Gómez, O.; Lemus, N.; Núñez, P.; Romero, L.; Vásquez, A.; Rosales, N. Carotenogénesis de cinco cepas del alga Dunaliella sp. (Chlorophyceae) aisladas de lagunas hipersalinas de Venezuela. Rev. Biol. Trop. 2005, 53, 331-337. [CrossRef] [PubMed]

31. Grama, B.S.; Agathos, S.N.; Jeffryes, C.S. Balancing photosynthesis and respiration increase microalgal biomass productivity during photoheterotrophy on glycerol. ACS Sustain. Chem. Eng. 2016, 4, 1611-1618. [CrossRef]

32. Cecchin, M.; Benfatto, B.; Griggio, F.; Mori, A.; Cazzaniga, S.; Vitulo, N.; Delledonne, M.; Ballottari, M. Molecular basis of autotrophic vs mixotrophic growth in Chlorella sorokiniana. Sci. Rep. 2018, 8, 6465. [CrossRef]

33. Marchello, A.E.; Dos Santos, A.C.; Lombardi, A.T.; Oliveira de Souza, C.W.; Montanhim, G.C. Physiological and ecological aspects of Chlorella sorokiniana (Trebouxiophyceae) under photoautotrophic and mixotrophic conditions. Microb. Ecol. 2018, 76, 791-800. [CrossRef]

34. Abiusi, F.; Wijffels, R.H.; Janssen, M. Doubling of microalgae productivity by oxygen balanced mixotrophy. ACS Sustain. Chem. Eng. 2020, 8, 6065-6074. [CrossRef]

35. Smith, J.K.P.; Hughes, A.D.; McEvoy, L.; Thornton, B.; Day, J.G. The carbon partitioning of glucose and DIC in mixotrophic, heterotrophic and photoautotrophic cultures of Tetraselmis suecica. Biotechnol. Lett. 2021, 43, 729-743. [CrossRef] [PubMed]

36. Pérez-García, O.; Bashan, Y. Microalgal heterotrophic and mixotrophic culturing for bio-refining: From metabolic routes to techno-economics. In Algal Biorefineries: Products and Refinery Design; Prokop, A., Bajpai, R., Zappi, M., Eds.; Springer International Publishing: Cham, Switzerland, 2015; pp. 61-131.

37. Lin, H.; Fang, L.; Low, C.S.; Chow, Y.; Lee, Y.K. Occurrence of glycerol uptake in Dunaliella tertiolecta under hyperosmotic stress. FEBS J. 2013, 280, 1064-1072. [CrossRef] [PubMed]

38. Moriyama, T.; Mori, N.; Sato, N. Activation of oxidative carbon metabolism by nutritional enrichment by photosynthesis and exogenous organic compounds in the red alga Cyanidioschyzon merolae: Evidence for heterotrophic growth. SpringerPlus 2015, 4, 559. [CrossRef]

39. Kaplan, A.; Schreiber, U.; Avron, M. Salt-induced metabolic changes in Dunaliella salina. Plant Physiol. 1980, 65, 810-813. [CrossRef]

40. Chen, H.; Jiang, J.; Wu, G. Effects of salinity changes on the growth of Dunaliella salina and its isozyme activities of Glycerol-3phosphate dehydrogenase. J. Agric. Food Chem. 2009, 57, 6178-6182. [CrossRef]

41. Yazdani, S.S.; González, R. Anaerobic fermentation of glycerol: A path to economic viability for the biofuels industry. Curr. Opin. Biotechnol. 2007, 18, 213-219. [CrossRef] [PubMed]

42. Wang, Z.; Zhuge, J.; Fang, H.; Prior, B.A. Glycerol production by microbial fermentation: A review. Biotechnol. Adv. 2001, 19, 201-223. [CrossRef]

43. Han, D.; Li, Y.; Hu, Q. Astaxanthin in microalgae: Pathways, functions and biotechnological implications. Algae 2013, 28 , 131-147. [CrossRef]

44. Cheah, W.Y.; Show, P.L.; Juan, J.C.; Chang, J.; Ling, T.C. Enhancing biomass and lipid productions of microalgae in palm oil mil effluent using carbon and nutrient supplementation. Energy Convers. Manag. 2018, 164, 188-197. [CrossRef]

45. Bardavid, R.E.; Khristo, P.; Oren, A. Interrelationships between Dunaliella and halophilic prokaryotes in saltern crystallizer ponds. Extremophiles 2008, 12, 5-14. [CrossRef]

46. White, S.; Anandraj, A.; Bux, F. PAM fluorometry as a tool to assess microalgal nutrient stress and monitor cellular neutral lipids. Bioresour. Technol. 2011, 102, 1675-1682. [CrossRef]

47. Xu, Y.; Ibrahim, I.M.; Harvey, P.J. The influence of photoperiod and light intensity on the growth and photosynthesis of Dunaliella salina (chlorophyta) CCAP 19/30. Plant Physiol. Biochem. 2016, 106, 305-315. [CrossRef]

48. Wang, X.; Zhang, M.M.; Liu, S.F.; Xu, R.L.; Mou, J.H.; Qin, Z.H.; Zhou, Z.G.; Li, H.Y.; Lin, C.S.; Sun, Z. Synergistic bioconversion of lipids and carotenoids from food waste by Dunaliella salina with fulvic acid via a two-stage cultivation strategy. Energy Convers. Manag. 2021, 234, 113908. [CrossRef]

49. Xu, S.; Elsayed, M.; Ismail, G.A.; Li, C.; Wang, S.; Abomohra, A.E. Evaluation of bioethanol and biodiesel production from Scenedesmus obliquus grown in biodiesel waste glycerol: A sequential integrated route for enhanced energy recovery. Energy Convers. Manag. 2019, 197, 111907. [CrossRef]

50. Tan, K.W.; Lee, Y.K. The dilemma for lipid productivity in green microalgae: Importance of substrate provision in improving oil yield without sacrificing growth. Biotechnol Biofuels 2016, 9, 255. [CrossRef] [PubMed]

51. Bashir, K.M.I.; Mansoor, S.; Kim, N.R.; Grohmann, F.R.; Shah, A.A.; Cho, M.G. Effect of organic carbon sources and environmental factors on cell growth and lipid content of Pavlova lutheri. Ann. Microbiol. 2019, 69, 353-368. [CrossRef]

52. Guedes, A.C.; Amaro, H.M.; Malcata, F.X. Microalgae as Sources of Carotenoids. Mar. Drugs 2011, 9, 625-644. [CrossRef] 
53. Cuaresma, M.; Casal, C.; Forján, E.; Vílchez, C. Productivity and selective accumulation of carotenoids of the novel extremophile microalga Chlamydomonas acidophila grown with different carbon sources in batch systems. J. Ind. Microbiol. Biotechnol. 2011, 38, 167-177. [CrossRef]

54. Mantzouridou, F.; Naziri, E.; Tsimidou, M.Z. Industrial glycerol as a supplementary carbon source in the production of betacarotene by Blakeslea trispora. J. Agric. Food Chem. 2008, 56, 2668-2675. [CrossRef]

55. Lao, Y.M.; Xiao, L.; Luo, L.X.; Jiang, J.G. Hypoosmotic expression of Dunaliella bardawil $\zeta$-carotene desaturase is attributed to a hypoosmolarity-responsive element different from other key carotenogenic genes. Plant Physiol. 2014, 165, 359-372. [CrossRef]

56. Mousavi, P.; Morowvat, M.H.; Montazeri-Najafabady, N.; Abolhassanzadeh, Z.; Mohagheghzadeh, A.; Hamidi, M.; Niazi, A.; Ghasemi, Y. Investigating the effects of phytohormones on growth and $\beta$-carotene production in a naturally isolates stain of Dunaliella salina. J. Appl. Pharm. Sci. 2016, 6, 164-171. [CrossRef]

57. Kasahara, H. Current aspects of auxin biosynthesis in plants. Biosci. Biotechnol. Biochem. 2016, 80, 34-42. [CrossRef] [PubMed]

58. Cifuentes, A.S.; Gonzalez, M.; Conejeros, M.; Dellarossa, V.; Parra, O. Growth and carotenogenesis in eight strains of Dunaliella salina Teodoresco from Chile. J. Appl. Phycol. 1992, 4, 111-118. [CrossRef]

59. Pourkarimi, S.; Hallajisani, A.; Alizadehdakhel, A.; Nouralishahi, A.; Golzary, A. Factors affecting production of beta-carotene from Dunaliella salina microalgae. Biocatal. Agric. Biotechnol. 2020, 29, 101771. [CrossRef]

60. Ben-Amotz, A.; Avron, M. On the factors which determine massive $\beta$-carotene accumulation in the halotolerant alga Dunaliella bardawil. Plant Physiol. 1983, 72, 593-597. [CrossRef]

61. Imamoglu, E.; Demirel, Z.; Dalay, M.C. Evaluation of culture conditions of locally isolated Dunaliella salina strain EgeMacc-024. Biochem. Eng. J. 2014, 92, 22-27. [CrossRef]

62. Sforza, E.; Pastore, M.; Barbera, E.; Bertucco, A. Respirometry as a tool to quantify kinetic parameters of microalgal mixotrophic growth. Bioprocess Biosyst. Eng. 2019, 42, 839-851. [CrossRef]

63. Guillard, R.R.L. Division rates. In Handbook of Phycological Methods. Culture Methods and Growth Measurements; Stein, J.R., Ed.; Cambridge University Press: Cambridge, UK, 1973; pp. 289-313.

64. Zhu, C.J.; Lee, Y.K. Determination of biomass dry weight of marine microalgae. J. Appl. Phycol. 1997, 9, 189-194. [CrossRef]

65. Wellburn, A.R. The spectral determination of chlorophylls $a$ and $b$, as well as total carotenoids, using various solvents with spectrophotometers of different resolution. J. Plant Physiol. 1994, 144, 307-313. [CrossRef]

66. Lichtenthaler, H.K.; Wellburn, A.R. Determination of total carotenoids and chlorophylls $a$ and $b$ of leaf in different solvents. Biochem. Soc. Trans. 1985, 11, 591-592. [CrossRef]

67. Van Heukelem, L.; Thomas, C.S. Computer-assisted high-performance liquid chromatography meted development with applications to the isolation and analysis of phytoplankton pigments. J. Chromatogr. 2001, 910, 31-49. [CrossRef]

68. Almazán-Becerril, A.; García-Mendoza, E. Maximum efficiency of charge separation of photosystem II of the phytoplankton community in the Eastern Tropical North Pacific of Mexico: A nutrient stress diagnostic tool? Cienc. Mar. 2008, $34,29-43$. [CrossRef]

69. Wright, S.; Montoura, R.F.C. Guidelines for collection and pigment analysis of marine samples. In Phytoplankton Pigments in Oceanography: Guidelines to Modern Methods; Jeffrey, S.W., Mantoura, R.F.C., Wright, S., Eds.; UNESCO Publishing: Paris, France, 1997; pp. 429-445.

70. Petrovic, U.; Plemenitas, A. Determination of intra-and extracellular concentration of glycerol in the halophilic black yeast Hortaea werneckii grown at different environmental salinities. In Non-Conventional Yeasts in Genetics, Biochemistry and Biotechnology; Wolf, K., Breunig, K., Barth, G., Eds.; Springer: New York, NY, USA, 2003; pp. 127-130.

71. Guenther, J.E.; Melis, A. Dynamics of Photosystem II heterogeneity in Dunaliella salina (green algae). Photosynth. Res. 1990, 23, 195-203. [CrossRef]

72. Gupta, S.; Pawar, S.B. Strategic mixed substrate cultivation of microalgae: Productivity, respiration, yield, and lipid quality. J. Appl. Phycol. 2019, 31, 1573-1588. [CrossRef]

73. Montgomery, D. Diseño y Análisis de Experimentos; LIMUSA Wiley: Mexico, D.F., Mexico, 2004; p. 692. 